\title{
PENINGKATAN KOMPETENSI PEDAGOGIK GURU SD MELALUI SUPERVISI AKADEMIK
}

\author{
Sri Giarti \\ sgiarty@gmail.com \\ Magister Manajemen Pendidikan - FKIP - UKSW Salatiga
}

\begin{abstract}
ABSTRAK
Tujuan penelitian ini adalah untuk meningkatkan kompetensi pedagogik guru kelas VI SD Negeri 2 Bengle melalui supervisi akademik. Jenis penelitian yang digunakan dalam penelitian ini adalah penelitian tindakan sekolah. Kegiatan dalam penelitian ini terdiri atas tahapan perencanaan tindakan, pelaksanaan tindakan, observasi, dan refleksi. Teknik pengumpulan data menggunakan teknik obeservasi kelas. Instrumen observasi yang digunakan adalah alat penilaian kemampuan guru (APKG) berupa: 1) instrument penilaian kemampuan guru dalam mengembangkan silabus, 2) instrument penilaian kemampuan guru dalam menyusun rencana pembelajaran, 3) instrument penilaian kemampuan guru dalam pelaksanaan pembelajaran. Analisis data yang digunakan adalah teknik analisis deskriptif komparatif. Data kuantitatif yang diperoleh di deskripsikan dalam bentuk kata-kata atau penjelasan. Selanjutkan dilakukan komparasi data untuk memastikan ada tidaknya peningkatan kemampuan guru dalam menyusun perencanaan pembelajaran, peningkatan kemampuan guru dalam pelaksanaan. Hasil penelitian menunjukkan temuan bahwa supervisi akademik dapat: a) meningkakan kemampuan guru kelas VI dalam mengembangkan silabus di SD Negeri 2 Bengle, Kecamatan Wonosegoro, Kabupaten Boyolali sebesar 41\%. b) meningkakan kemampuan guru kelas VI dalam menyususn rencana pembelajaran di SD Negeri 2 Bengle, Kecamatan Wonosegoro, Kabupaten Boyolali sebesar 39\%. c) meningkakan kemampuan guru kelas VI dalam melaksanakan pembelajaran di SD Negeri 2 Bengle, Kecamatan Wonosegoro, Kabupaten Boyolali sebesar 34\%
\end{abstract}

Kata kunci: supervisi akademik, kompetensi pedagogik

\section{PENDAHULUAN}

Guru merupakan pekerjaan yang harus ditekuni untuk mewujudkan keahlian yang profesionalnya. Sebagai tenaga professional guru mempunyai peranan dan tanggung jawab terhadap kegiatan pembelajaran. Guru Sekolah Dasar mempunyai peranan penting karena memberikan pondasi bagi peningkatan sumber daya manusia sejak dini. Keberhasilan seorang anak didik mengikuti pendidikan di sekolah menengah dan perguruan tinggi sangat ditentukan pada keberhasilannya mengikuti pendidikan di sekolah dasar. Oleh karena itu di sekolah dasar diperlukan guru yang profesional untuk dapat meningkatkan mutu pendidikan, misalnya pada saat kegiatan kegiatan belajar mengajar guru tidak hanya sekedar menyampaikan 
materi namun kegiatan pembelajaran yang bermuara pada perubahan perilaku siswa. Selain mengajar guru juga mempunyai tugas mendidik, mengajar, dan membimbing siswa dengan memberikan keterampilan sebagai sebagai bekal hidup dalam masyarakat.

Tugas dan fungsi guru tersebut di atas sejalan dengan yang diamanatkan dalam Undang-Undang Nomor 14 Tahun 2005 tentang Guru dan Dosen mengemukakan bahwa seorang guru adalah pendidik professional dengan tugas utama mendidik, mengajar, membimbing, mengarahkan, melatih, menilai, dan mengevaluasi peserta didik pada jalur pendidikan formal, pendidikan dasar, dan pendidikan menengah. Dalam melaksanakan tugas keprofesionalnya diperlukan pemahaman mengenai konsep belajar dan pengembangan kurikulum dalam bentuk penyusunan silabus, penyusunan rencana pelaksanaan pembelajaran (RPP), dan mampu mengimplementasikan dalam kegiatan belajar mengajar. Pemahaman konsep belajar yang dimaksud ialah kegiatan guru untuk memperoleh pengetahuan, perilaku, dan keterampilan untuk membentuk pengalaman belajar sehingga dapat memperbaiki kualitas pembelajaran.

Namun, pada kenyataannya masih jauh dari harapan. Hasil observasi pendahuluan yang dilakukan oleh guru di SD $\mathrm{N} 2$ Bengle menunjukkan 1) kemampuan guru dalam mengembangkan silabus masih rendah yaitu berada pada skor 50 atau kategori kurang, guru terlihat belum mengembangkan silabus mereka hanya menggunakan silabus dari pemerintah tanpa disesuaikan dengan karakteristik siswanya. 2) kemampuan guru dalam penyusunan rencana pembelajaran berada pada skor 56 atau kategori kurang guru nampak tidak menyusun RPP, hanya menggunakan RPP yang telah ada.

Rendahnya kemampuan guru dalam mengembangkan silabus dan penyusunan rencana pembelajaran berdampak pada rendahnya kemampuan guru dalam melaksanakan pembelajaran. kemampuan guru dalam pelaksanaan pembelajaran pelaksanaan pembelajaran pada skor 60 atau kategori cukup. Hal ini nampak bahwa pembelajaran sangat didominasi oleh guru, guru belum menggunakan model pembelajaran yang kreatif, tidak mengembangkan media pembelajaran sehingga menimbulkan siswa menjadi pasif.

Berdasarkan fenomena diatas peneliti berupaya melakukan perbaikan dalam rangka peningkatan mutu pendidikan di sekolah. menggunakan supervisi akademik. Kajian pustaka yang dilakukan peneliti menemukan informasi mengenai kegiatan supervisi yang sangat potensial untuk meningkatkan profesionalitas guru.

Arikunto Suharsimi (2006:5) menyebutkan bahwa ditinjau dari kegiatannya, supervisi ada dua yaitu supervisi akademik dan supervisi administrasi. Dari dua kegiatan supervisi yang ada, supervisi akademik merupakan kegiatan yang sangat potensial untuk meningkatkan kompetensi pedagogik guru. Potensi supervisi akademik tersebut oleh karena lingkupnya langsung pada kegiatannya 
pembelajaran.

Supervisi akademik sama maksudnya dengan konsep supervisi pendidikan (educational supervision) sering disebut pula sebagai Instrukional Supervision atau Instrukional Leadership, yang menjadi fokusnya adalah mengkaji, menilai, memperbaiki, meningkatkan, dan mengembangkan mutu kegiatan belajar mengajar yang dilakukan guru melalui pendekatan bimbingan dan konsultasi dalam nuansa dialog profesional.

Berdasarkan latar belakang seperti tersebut di atas, permasalahan penelitian yang akan dipecahkan adalah apakah supervisi akademik dapat meningkakan kompetensi pedagogik guru SD dan bagaimana supervisi akademik dapat meningkatkan kompetensi pedagogik guru SD.

\section{KAJIAN PUSTAKA}

\section{Hakikat Kompetensi}

Guru merupakan orang profesional atau ahli yang memerlukan kompetensi dalam menjalankan pekerjaannya. Menurut Sagala Syaiful (2009:209) kompetensi merupakan kemampuan yang harus dimiliki oleh guru dalam menjalankan tugas dengan profesional. Sedangkan Daryanto dan Tasrial (2011:1) mengatakan bahwa kompetensi merupakan seperangkat pengetahuan, keterampilan, dan perilkau yang harus dimiliki, dihayati, dan dikuasai oleh guru dalam melaksanakan tugas profesionalannya.

Sejalan dengan dengan Sagala Saiful (2009), Daryanto dan Tasrial (2015) Undang-Undang Nomor 14 Tahun 2005 menyebutkan bahwa guru mempunyai kedudukan sebagai tenaga profesional yang berfungsi untuk meningkatkan mutu pendidikan nasional.

Dari pendapat diatas dapat disimpulkan bahwa guru merupakan tenaga profesional yang harus memiliki dan menguasai pengetahuan, keterampilan dan perilaku untuk meningkatkan mutu pendidikan nasional. Dalam mengemban tugasnya guru perlu memiliki kompetensi meliputi kompetensi kepribadian, kompetensi pedagogik, kompetensi profesional, dan kompetensi sosial yang diperoleh melalui pendidikan profesi. Dari empat kompetensi tersebut, dalam penelitian ini kompetensi pedagogik menjadi salah satu kompetensi yang perlu dikembangkan karena sesuai dengan kebutuhan seperti telah dipaparkan pada bagian latar belakang masalah.

Kompetensi pedagogik merupakan kemampuan mengelola pembelajaran. Terkait dengan standar kompetensi pedagogik, Dirjen PMPTK (2012:42) menetapkan bahwa kompetensi inti yang harus dimiliki oleh seorang guru dengan pedoman pelaksanaan penilaian kinerja guru meliputi: 1) mengenal karakteristik peserta didik, 2) menguasai teori belajar dan prinsip-prinsip pembelajaran yang mendidik, 3) pengembangan kurikulum, 4) kegiatan pembelajaran yang mendidik, 
5) pengembangan potensi peserta didik, 6) komunikasi dengan peserta didik, 7) penilaian dan evaluasi.

Lebih lanjut Dirjen PMPTK (2012:71) merumuskan pedoman pengukuran kompetensi pedagogik yaitu: 1) menyusun alat penilaian sesuai dengan tujuan pembelajaran (RPP), 2) melaksanakan penilaian, 3) menganalisa hasil penilaian, 4) memanfaatkan masukan dari peserta didik dan merefleksikan, 5) memanfaatkan hasil penilaian sebagai penyusunan rancangan pembelajaran selanjutnya.

Berdasarkan uraian tentang definisi kompetensi dan standar kompetensi pedagogik guru seperti telah diuraikan di atas, terlihat bahwa kompetensi guru SD hakikatnya merupakan konkretisasi dari sebuah kemampuan, pengetahuan, dan keterampilan yang dimiliki guru SD dalam menjalankan tugas keprofesiannya untuk menciptakan kualitas pembelajaran.

Upaya-upaya peningkatan kompetensi pedagogik guru SD sering dilakukan dengan berbagai cara, salah satu caranya dengan kegiatan supervisi. Kegiatan supervisi merupakan implementasi untuk meningkatkan kemampuan guru dalam mengembangkan keprofesionalan dengan memperbaiki dan meningkatkan proses pembelajaran yang dilakukan oleh kepala sekolah.

\section{Hakikat Supervisi Akademik}

Secara etimologis supervisi berasal dari kata super artinya atas dan visi yang artinya penglihatan, jadi supervisi adalah posisi yang melihat atau kedudukan yang lebih tinggi daripada yang dilihat. Sedangkan dalam bahasa inggris yaitu supervision yang artinya pengawasan (Engkoswara dan Komariah, 2010:228). Berdasarkan dua hal tersebut, maka supervisi dapat diartikan sebagai pengawasan yang dilakukan oleh orang yang memiliki kedudukan yang lebih tinggi atau orang ahli/professional.

Danim dan Khairil, (2011:154) yang mengatakan bahwa supervisi pendidikan sering diartikan sebagai upaya peningkatan mutu proses dan hasil pembelajaran melalui bimbingan profesional oleh pengawas sekolah. Bimbingan profesional yang dimaksud yaitu memberikan kesempatan kepada guru untuk berkembang secara profesional dalam menjalankan tugas pokoknya yaitu memperbaiki dan meningkatkan proses belajar.

Selanjutnya, Good Carter dikutip oleh Daryanto (2010:170) menjelaskan bahwa supervisi merupakan usaha dari pejabat sekolah dalam memimpin guru dan tenaga pendidikan lain untuk memperbaiki pengajaran, memberi stimulasi pertumbuhan dan perkembangan guru, merevisi tujuan pendidikan, bahan pengajaran, metode mengajar hingga evaluasi pengajaran. 
Sejalan dengan pendapat Good Carter, Neagley dan Evans dikutip oleh Sagala (2010:91) mendefinisikan supervisi sebagai bantuan yang diberikan untuk guru untuk meningkatkan kualitas pembelajaran, pendidikan dan kurikulum.

Berdasarkan beberapa pendapat yang telah dikemukakan, penulis menyimpulkan bahwa supervisi merupakan serangkaian kegiatan yang dilakukan oleh pejabat sekolah untuk meningkatkan kemampuannya guru untuk berkembang secara profesional sehingga guru dapat maju dalam menjalankan tugasnya yaitu memperbaiki dan meningkatkan proses pembelajaran. pejabat sekolah yang dimaksud adalah kepala sekolah.

Menurut Glickman (1981) dikutip oleh direktorat jenderal peningkatan mutu pendidik dan tenaga kependidikan departemen pendidikan nasional (2008:21) mendefinisikan supervisi akademik merupakan serangkaian kegiatan membantu guru mengembangkan kemampuannya mengelola proses pembelajaran demi pencapaian tujuan pembelajaran.

Selanjutnya Sudjana Nana dkk (2011:19) menyebutkan bahwa Supervisi akademik merupakan fungsi pengawas berkenaan dengan aspek pelaksanaan tugas pembinaan, pemantauan, penilaian dan pelatihan profesional guru dalam (1) merencanakan pembelajaran; (2) melaksanakan pembelajaran; (3) menilai hasil pembelajaran; (4) membimbing dan melatih peserta didik, dan (5) melaksanakan tugas tambahan yang melekat pada pelaksanaan kegiatan pokok sesuai dengan beban kerja guru.

Berdasarkan uraian tentang hakikat supervisi akademik seperti telah diuraiakan diatas, maka hakikat supervisi merupakan serangkaian kegiatan untul membantu guru-guru mengembangkan kemampuannya mencapai tujuan pembelajaran. Kegiatan yang dimaksud adalah pembinaan, pemantauan, penilaian dan pelatihan profesionalisme guru. Supervisi akademik ini menitikberatkan pada masalah-masalah akademik, yaitu hal-hal yang berlangsung dalam lingkungan kegiatan pembelajaran pada waktu siswa sedang dalam proses belajar.

Permendiknas no. 39 tahun 2009 menyebutkan bahwa ruang lingkup supervisi akademik meliputi: a) membina guru dalam merencanakan, melaksanakan dan menilaia proses pembelajaran, b) memantau pelaksanaan standar isi, c) memantau pelaksanaan standar proses, d) memantau pelaksanaan standar kompetensi kelulusan, e) memantau pelaksanaan standar tenaga pendidik dan f) memantau pelaksanaan standar penilaian.

Berpijak pada ruang lingkup supervisi seperti telah dipaparkan diatas, mala penelitian ini dilakukan untuk mengembangkan kompetensi guru dalam merencanakan, melaksanakan dan menilai proses pembelajaran melalui supervisi akademik. 


\section{Peningkatan Kompetensi Pedagogik Guru Melalui Supervisi Akademik}

Peningkatkan mutu guru yang berkualitas perlu dilakukan secara terprogram, terstruktur dan berkelanjutan melalui pembinaan profesional oleh kepala sekolah sehingga mampu menampung berbagai masalah yang dihadapi oleh guru dalam proses pembelajaran untuk dapat menemukan cara-cara pemecahan permasalahan melalui supervisi akademik. Esensi supervisi akademik bukanlah menilai unjuk kerja guru dalam mengelola proses pembelajaran, melainkan untuk membantu guru mengembangkan kemampuan profesionalismenya.

Walaupun dalam prosesnya tidak lepas dari kegiatan menilai guru. Wajar jika supervisi akademik dianggap sebagai penilaian guru dikarenakan supervisi lebih banyak dilakukan dalam bentuk pengamatan mengajar guru. Penilaian dalam mengelola proses pembelajaran sebagai suatu proses pemberian estimasi kualitas unjuk kerja guru dalam mengelola proses pembelajaran, merupakan bagian yang tak terpisahkan dari serangkaian kegiatan supervisi

Bertolak dari hal tersebut, kebijakan untuk meningkatkan mutu pendidikan pada hakikatnya merupakan keputusan yang strategis. Mutu pendidikan pada umumnya dapat dilihat dari dua segi yaitu segi proses dan segi produk. Dari segi proses, pendidikan dapat disebut bermutu apabila proses pembelajaran berlangsung secara efektif sehingga menghasilkan produk yang berkualitas. Sedangkan dari segi produk, hasil pendidikan disebut bermutu jika peserta didik menunjukkan tingkat penguasaan yang tinggi terhadap tugas-tugas belajar yang dinyatakan dalam prestasi belajar; hasil pendidikan sesuai dengan kebutuhan peserta didik dalam kehidupannya; hasil pendidikan yang sesuai atau relevan dengan tuntutan lingkungan, khususnya dunia kerja (Depdikbud, 1996).

\section{METODE PENELITIAN}

Penelitian ini merupakan penelitian tindakan sekolah (PTS) yang dilakukan di SD Negeri 2 Bengle, Kecamatan Wonosegoro Boyolali kelas VI Semester 1 Tahun Pelajaran 2015/ 2014. Pelaksanaan penelitian tindakan sekolah ini dilakukan melalui tahapan penyusunan proposal penelitian, penyusunan instrument, pelaksanaan tindakan dalam rangka pengumpulan data, analisis data dan pembahasan hasil penelitian serta penyusunan laporan PTS.

Subyek yang dilibatkan dalam penelitian tindakan sekolah ini adalah guru kelas VI. Sumber data primer berasal dari hasil pengukuran variabel penelitian tindakan sekolah berikut: 1) skor kemampiuan guru dalam mengembangkan silabus, 2) skor kemampuan guru dalam penyusunan rencana pembelajaran, 3) skor kemampuan guru dalam pelaksanaan pembelajaran.

Teknik pengumpulan data menggunakan teknik obeservasi kelas. Instrumen observasi yang digunakan adalah alat penilaian kemampuan guru (APKG) berupa: 
1) instrument penilaian kemampuan guru dalam mengembangkan silabus, 2) instrument penilaian kemampuan guru dalam menyusun rencana pembelajaran, 3) instrument penilaian kemampuan guru dalam pelaksanaan pembelajaran. Kisi-kisi instrumen pengukuran kemampuan guru dalam mengembangkan silabus mencakup 7 komponen, yaitu komponen mengkaji Standar Kompetensi dan Kompetensi Dasar (item no. 1, 2, 3), mengidentifikasi materi pokok pembelajaran (item no 4, 5, 6, 7, 8, 9, 10, 11),mengembangkan kegiatan pembelajaran (item no 12, 13, 14, 15), merumuskan indikator pencapaian kompetensi (item no 16, 17, 18, 19, 20), penentuan jenis penilaian (item no 21, 22, 23, 24), menentukan alokasi waktu (25 dan 26), menentukan sumber belajar (27, dan 28).

Kisi-kisi instrument instrument kemampuan guru dalam menyusun rencana pembelajaran mencakup 7 komponen yaitu: tujuan pembelajaran (no item 1 dan 2) meteri ajar (no item 3, 4, 5 ), metode pembelajaran (no item 6 dan 7), langkahlangkah pembelajaran (no item 8, 9, 10 11, 12, 13, 14, 15, 16, 17) alat/bahan/sumber belajar (no item 18, 19, 20), penialain (no item 21 dan 22), kesan umum rencana pembelajaran (no item 23, 24, 25). Sedangkan untuk instrument kemampuan guru dalam pelaksanaan pembelajaran mencakup 3 komponen yaitu kegiatan awal (no item 1, 2, 3) kegiatan inti (no item 4, 5, 6, 7, 8, 9, 10, 11, 12, 13, 14, 15, 16, 17) kegiatan akhir (no item 18 dan 19).

Tiap instrumen penilaian terdapat 5 kualifikasi penilaian yaitu 1, 2, 3, 4 dan 5. Setiap skor yang diperoleh kemudian dibagi dengan skor maksimal dan dikalikan dengan 100 atau $\mathrm{N}=\frac{\text { skor yang diperoleh }}{\text { skormaksimal }} X$ 100. Adapun kriteria penilaian yaitu: Baik Sekali berada di skor 91 sampai 100, Baik berada pada skor 76 sampai 90, Cukup berada pada skor 61 sampai 75, Kurang berada pada skor 51 sampai 60 sedangkan Kurang Sekali berada pada skor kurang dari 50.

Analisis data yang digunakan adalah teknik analisis deskriptif komparatif. Data kuantitatif yang diperoleh di deskripsikan dalam bentuk kata-kata atau penjelasan. Selanjutkan dilakukan komparasi data untuk memastikan ada tidaknya peningkatan kemampuan guru dalam menyusun perencanaan pembelajaran, peningkatan kemampuan guru dalam pelaksanaan.

Sebagai tolok ukur keberhasilan pelaksanaan penelitian tindakan kelas ini ditetapkan indikator kinerja sebagi berikut: 1) Persentase jumlah jumlah skor perolehan kemampuan mengembangkan silabus sebesar 35\% 2) Persentase jumlah jumlah skor perolehan kemampuan menyusun perencanaan pembelajaran sebesar $35 \%$ dan 3) Persentase jumlah jumlah skor perolehan kemampuan pelaksanaan pembelajaran sebesar $30 \%$

\section{HASIL DAN PEMBAHASAN}

Setelah melakukan analisa terhadap data yang diperoleh, maka dapat disimpulkan bahwa penggunaan supervisi akademik menunjukkan peningkatan 
kompetensi pedagogik. Tabel 1 merangkum komparasi kemampuan merencanakan pembelajaran, dari kondisi awal, dan tindakan.

\section{Tabel 1 Komparasi Kompetensi Guru}

\begin{tabular}{|l|c|c|c|}
\hline \multirow{2}{*}{ Kompetensi guru } & \multicolumn{3}{|c|}{ Pelaksanaan Supervisi } \\
\cline { 2 - 4 } & $\begin{array}{c}\text { Kondisi } \\
\text { Awal }\end{array}$ & Tindakan & kenaikan \\
\hline $\begin{array}{l}\text { Mengembangan } \\
\text { silabus }\end{array}$ & 50 & 91 & $41 \%$ \\
\hline $\begin{array}{l}\text { Menyusun rencana } \\
\text { pembelajaran }\end{array}$ & 56 & 95 & $39 \%$ \\
\hline $\begin{array}{l}\text { Malaksanakan } \\
\text { pembelajaran }\end{array}$ & 60 & 94 & $34 \%$ \\
\hline
\end{tabular}

Dari data dalam Tabel diatas, diperoleh temuan kemampuan guru dalam mengembangkan silabus: a) pada kondisi awal, baru mencapai skor 50 (skor maksimal 100) atau masuk kategori sangat kurang. Hal ini dikarenakan guru belum mengembangkan silabus, hanya menggunakan silabus dari pemerintah yang sifatnya gobal dan belum disesuaikan dengan karakteristik peserta didik. b) pada tindakan, skor guru mencapai 91 atau kategori sangat baik capaian ini menunjukkan peningkatan kemampuan guru mengembangkan silabus.

Temuan kedua, kemampuan guru dalam menyusun rencana pembelajaran. a) kondisi awal, baru mencapai skor 56 (skor maksimal 100) atau masuk dalam kategori kurang. Hal ini disebabkan karena guru beum membuat RPP, guru hanya menggunakan RPP yang sudah ada. b) pada tindakan, skor guru mencapai 95 atau kategori sangat baik, capaian ini menunjukkan peningkatan kemampuan guru dalam menyusun rencana pembelajaran.

Temuan ketiga, kemampuan guru dalam melaksanakan pembelajaran a) konndisi awal, baru mencapai skor 60 (skor maksimal 100) atau masuk kategori kurang. Kondisi ini menunjukkan guru belum menggunakan model pembelajaran yang aktif dan menyenangkan, pembelajaran masih didonminasi oleh guru sehingga peserta didik tidak aktif pada saat pembelajaran. b) pada tindakan skor guru mencapai 94atau kategori sangat baik, capaian ini menunjukkan peningkatan kemampuan guru dalam melaksanakan pembelajaran.

\section{Keberhasilan supervisi akademik dalam meningkatkan kemampuan guru mengembangkan silabus}

Data pada tabel kompetensi guru kondisi dan tindakan menunjukkan temuan skor kemampuan guru mengembangkan silabus pada kondisi awal 50 pada tindakan 91.Temuan ini mengindikasikan adanya peningkatan tingkat kemampuan guru mengembangkan silabus. Besaran peningkatan 41\%. Jika 
dibandingkan dengan indikator kinerja 35\% ternyata temuan tersebut telah mencapai keberhasilan.

\section{Keberhasilan supervisi akademik dalam meningkatkan kemampuan menyusun rencana pembelajaran}

Data pada tabel kompetensi guru kondisi awal dan tindakan menunjukkan temuan skor kemampuan guru menyusun rencana pembelajaran pada kondisi awal 56 pada tindakan 95. Temuan ini mengindikasikan adanya peningkatan tingkat kemampuan guru menyusun rencana pembelajaran. Besaran peningkatan $39 \%$. Jika dibandingkan dengan indikator kinerja 35\% ternyata temuan tersebut telah mencapai keberhasilan.

\section{Keberhasilan supervisi akademik dalam meningkatkan kemampuan melaksanakan pembelajaran}

Data pada tabel kompetensi guru kondisi dan tindakan menunjukkan temuan skor kemampuan guru melaksanakan pembelajaran pada kondisi awal 60 pada tindakan 94. Temuan ini mengindikasikan adanya peningkatan tingkat kemampuan guru melaksanakan pembelajaran. Besaran peningkatan 34\%. Jika dibandingkan dengan indikator kinerja 30\% ternyata temuan tersebut telah mencapai keberhasilan.Temuan ini sejalan dengan penelitian Parwati Santi dkk (2013), Dalawi dkk (2012), dan Banun Sri Haksasi (2013).

\section{SIMPULAN DAN SARAN}

\section{Simpulan}

Berdasarkan hasil penelitian dan pembahasan, dapat disimpulkan bahwa supervisi akademik dapat:

1. Meningkakan kemampuan guru kelas VI dalam mengembangkan silabus di SD Negeri 2 Bengle, Kecamatan Wonosegoro, Kabupaten Boyolali sebesar 41\%

2. Meningkakan kemampuan guru kelas VI dalam menyususn rencana pembelajaran di SD Negeri 2 Bengle, Kecamatan Wonosegoro, Kabupaten Boyolali sebesar 39\%

3. Meningkakan kemampuan guru kelas VI dalam melaksanakan pembelajaran di SD Negeri 2 Bengle, Kecamatan Wonosegoro, Kabupaten Boyolali sebesar 34\%

\section{Saran}

Saran yang diajukan dalam penelitian ini adalah, kepala sekolah hendaknya: a) menggunakan supervisi akademik untuk memperbaiki pembelajaran, b) melatih guru untuk berpartisipasi aktif dalam pengembangkan pembelajaran di kelas. 


\section{DAFTAR PUSTAKA}

Arikunto, Suharsimi. 2006. Dasar-Dasar Supervisi. Jakarta: Rineka Cipta

Banun Sri Haksasi. 2013. Pelaksanaan Supervisi Akademik Pada SMA Negeri 3 Semarang. Majalah Ilmiah Pawiyatan, $(x x): 4$

Dalawi, Amrazi Zakso, Usman Radiana. 2012. Pelaksanaan Supervisi Akademik Pengawas Sekolah Sebagai Upaya Peningkatan Profesionalisme Guru SMP Negeri 1 Bengkayang. Thesis S2 AP, FKIP Universitas Tanjungpura, Pontianak

Danim Sudarwan dan Khairil. 2011. Profesi Kependidikan. Bandung: Alfabeta.

Daryanto. 2010. Administrasi Pendidikan. Jakarta: Rineka Cipta.

Daryanto dan Tasrial. 2011. Konsep Pembelajaran Kreatif. Yogyakarta: Gavamedia

Depdiknas. 2005. Undang-Undang Nomor 14 Tahun 2005 Tentang Sistem Pendidikan Nasional. Jakarta: Depdiknas. . 2009. Undang-Undang Nomor 39 tahun 2009 Tentang pemenuhan Beban Kerja Guru dan Pengawas Satuan Pendidikan. Jakarta

Dirjen PMPTK. 2008. Metode dan teknik supervisi. Jakarta: Kementerian Pendidikan dan Kebudayaan.

Dirjen PMPTK. 2012. Pedoman pelaksanaan kinerja guru (PK Guru). Buku 2. Jakarta: kementerian Pendidikan dan Kebudayaan.

Engkoswara dan Komariah Aan. 2010. Administrasi Pendidikan. Bandung: Alfabeta.

Parwati Santi Desak Putu, Dantes Nyoman dan Natajaya Nyoman. 2013 Implementasi Supervisi Akademik dalam Rangka Peningkatan Kemampuan Menyusun RPP pada Guru Matematika SD Anggota KKG Gugus IV Kecamatan Sukasada. e-Journal Program Pascasarjana Universitas Pendidikan Ganesha Jurusan Pendidikan Dasar (3) Vol 4. (4).

Sagala Syaiful. 2009. Administrasi Pendidikan Kontemporer. Bandung: Alfabeta

Sagala Syaiful. 2010. Supervisi Pembelajaran. Bandung. Alfabeta

Nana Sudjana. 2011. Buku Kerja Pengawas Sekolah. Pusat Pengembangan Tenaga Kependidikan, Badan PSDM dan PMP. Jakarta: Kemdikbud 